POLLACK PERIODICA

An International Journal for Engineering and Information Sciences DOI: $10.1556 / 606.2017 .12 .3 .1$

Vol. 12, No. 3, pp. 3-13 (2017)

www.akademiai.com

\title{
COMPARISON OF THE MODFLOW MODULES FOR THE SIMULATION OF THE RIVER TYPE BOUNDARY CONDITION
}

\author{
${ }^{1}$ Petr DUŠEK, ${ }^{2}$ Yvetta VELÍSKOVÁ \\ Institute of Hydrology, Slovak Academy of Sciences, Dúbravská cesta 9, 84101 \\ Bratislava, Slovakia, e-mail: 1dusek@uh.savba.sk, ${ }^{2}$ veliskova@uh.savba.sk
}

Received 4 January 2017; accepted 24 April 2017

\begin{abstract}
The aim of this article is the comparison of input options of river boundary condition of MODFLOW - three-dimensional numerical simulation model of groundwater flow. The water level in stream flowing through territory of hydrogeological layer can be computed via three built-in modules: River, Stream and Streamflow-Routing. In this study the code MODFLOW is used to simulate idealized aquifer and stream. The differences between computed groundwater table showed to be minimal, thus in case of modules Stream and StreamflowRouting they are equally usable as using module River with external one or two-dimensional simulation of surface water flow, which is more time-consuming process. However, this applies only to idealized, simplified conditions of the modeled environment. For more complex simulation of flow in streams with irregular structure of the streambed is necessary to use either an external simulation or use the Streamflow-Routing module, which includes the possibility to enter more complex hydraulic flow parameters in the model.
\end{abstract}

Keywords: Surface water, Groundwater, Interaction, Numerical simulation, Flow regime

\section{Introduction}

Water table is an important factor of Ground-Water (GW) - Surface Water (SW) interaction. Stream level elevation is influenced by stream morphology, its width and depth, roughness, by obstacles, and by the volume of water flowing through the stream [1]. Three water flow types are involved: free surface flow in the stream, saturated groundwater flow in the aquifer and unsaturated flow in the vadose zone [2]. In case of modeling GW-SW interaction with time-dependent changes in SW level or when there is no possibility to measure level directly it is needed to create a simulation of SW level 
as well. With integrated numerical simulations, it is possible to directly compute surface water stages as a part of GW simulation, or specialized software can be used to simulate SW independently of the main GW numerical simulation [3]. The aim of this paper is to compare the head-dependent flux boundary packages for the three-dimensional numerical model MODFLOW [2]. There are three integrated modules that are used to represent river boundary condition in the model: RIV (River) [4], STR (Stream) [5] and SFR (Streamflow-Routing) [6], [7].

\section{Methods}

MODFLOW is a three-dimensional numerical model, which is used for simulation of groundwater flow regime in an aquifer or aquifers and at the same time is used for the quantification of interaction between SW and GW. For numerical representation of a stream three SW boundary condition modules can be used. As mentioned above the modules are RIV [4], STR [5] and SFR1 [8] or SFR2 [9] respectively.

\section{RIV module}

Rivers and streams can gain water from the aquifer or lose water to the aquifer. This process depends on the surface water level and groundwater table difference. Influence of the SW level on the GW-SW interaction can be simulated in MODFLOW by RIV module. For this it is needed to specify the seepage defining parameters that are integrated in the computation of the groundwater flow equation in each of the MODFLOW numerical simulation grid model cells. The seepage between the stream and the aquifer is simulated for each stream reach and for each model cell that the stream intersects. The RIV module does not compute surface water levels by its own; they need to be specified manually for all nodes of boundary condition that represent the start and the end of a single reach. The RIV module does not simulate surface water flow in the river - only the river/aquifer seepage [2]. Other modules included in the MODFLOW code simulate both the seepage and the surface water regime based on discharge. The cross section in Fig. 1 shows the stream that intersects the model cell. In the conceptualized system (Fig. Ia) the surface water is separated from the groundwater by a layer of streambed sediment with a low coefficient of saturated hydraulic conductivity. In the idealized environment (Fig. 1 b) the connection between a river and an aquifer is represented by one dimensional seepage through a conductance parameter.

It is assumed that the significant loses of the head occur only through the less permeable streambed sediments layer. At the same time, it is assumed that the model cell below the streambed layer is fully saturated, thus that the groundwater table is always equal or higher that the elevation of the streambed layer. Considering these assumptions, the seepage between river and aquifer can be calculated as follows:

$$
Q R I V_{n}=C R I V_{n}\left(H R I V_{n}-h_{i, j, k}\right),
$$


where $Q R I V_{n}\left[\mathrm{~m}^{3} \cdot \mathrm{s}^{-1}\right]$ is the seepage between an aquifer and a stream; $C R I V_{n}\left[\mathrm{~m}^{2} \cdot \mathrm{s}^{-1} \cdot \mathrm{m}^{-1}\right]$ is the conductance parameter; $\operatorname{HRIV}_{n}[\mathrm{~m}]$ is the surface water level; $h_{i, j, k}[\mathrm{~m}]$ is the groundwater head elevation below a stream.

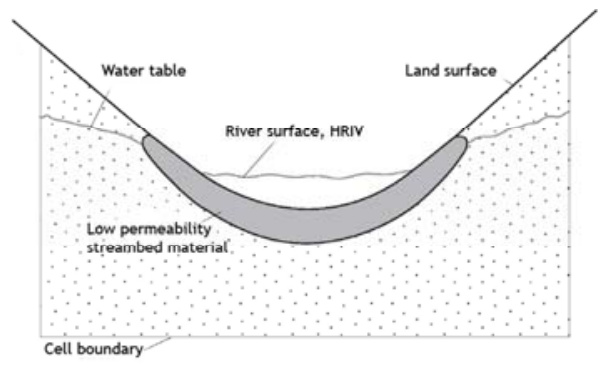

a)

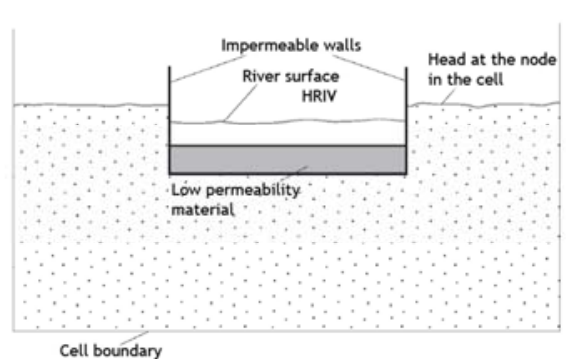

b)

Fig. 1. a) Cross section of an aquifer and river, b) conceptualization of connection of aquifer and river in the MODFLOW model [3]

Fig. 2 shows the isolated bottom sediment layer and parameters that are included in the equation for seepage amount calculation. The length $L_{n}[\mathrm{~m}]$ of bottom sediment is the length of the river reach that intersects the model cell. $W_{n}[\mathrm{~m}]$ is the width of river; $M_{n}[\mathrm{~m}]$ is the thickness of streambed sediment layer and $K_{n}\left[\mathrm{~m} . \mathrm{s}^{-1}\right]$ is the hydraulic conductivity of streambed material. Then the conductance $C R I V_{n}$ is then computed as

$$
C R I V_{n}=\frac{K_{n} L_{n} W_{n}}{M_{n}}
$$

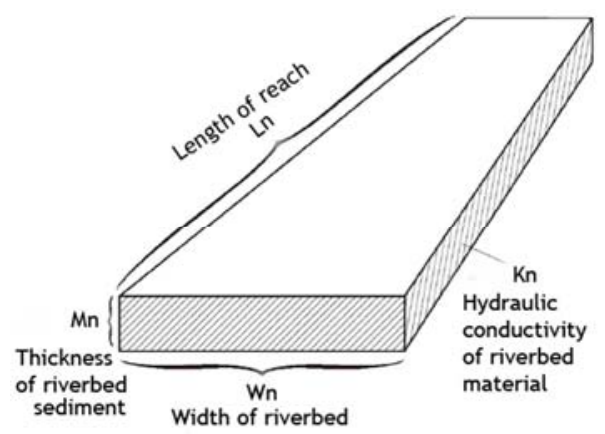

Fig. 2. Conceptualization of a streambed sediment and the conductance parameter [4]

Fig. 3 shows direction of flow into a river reach on the GW head elevation below a river, in the cell containing river reach. Flow is zero when $h$ is equal to the water level in the river, $(h=H R I V)$. For values of $h$ higher than $H R I V$, water flows into the river. It is represented as a negative inflow to aquifer. For values of $h$ lower than HRIV, water flows into an aquifer and the value of seepage is positive. This positive flow increases 
linearly with $h$ decreasing, until $h$ reaches River BOTtom (RBOT); thereafter the flow remains constant. The conceptualization of river-aquifer interaction used here assumes that this interaction is independent on the location of river reach within cell, and that the level of water in river is uniform over the reach and constant over each stress period [10]. The latter assumption implies that conditions of flow in the river do not vary substantially during the stress period - for example, river does not go dry or overflow its banks, or duration of those events are so short that they have no effect on GW-SW interaction [11].

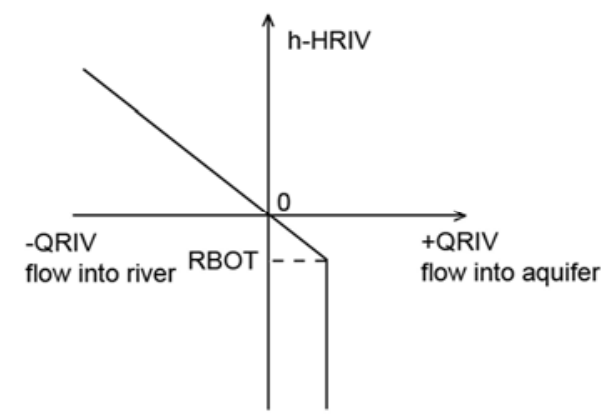

Fig. 3. The diagram of the seepage between surface water and groundwater through the streambed sediment [4]

\section{STR module}

STR (Stream) module [5] can simulate surface water flow regime and effect of it on groundwater regime, as well. This module represents the evolution step of the RIV module and predecessor of the SFR module. It uses simplified hydraulic parameters of stream and Manning's formula for the computation of the surface water level. The flow in the stream is specified by a discharge in the first reach of a river that enters the model grid. Discharge in the adjacent reaches is computed as the difference between the discharge from the previous reach and the seepage (positive or negative) through the bottom sediment layer. The scheme of the computation assumes that the flow from previous reaches is instantaneously available at the next reach in flow direction. This assumption is acceptable considering the relative slow movement of groundwater [12].

\section{Surface water level computation}

The STR module implements the surface water level computation for each reach of river. If this option is used, water level regime is computed using Manning's equation [13]:

$$
Q=\frac{1}{n}\left(A R^{2 / 3} S^{1 / 2}\right),
$$


where $Q\left[\mathrm{~m}^{3} \cdot \mathrm{s}^{-1}\right]$ is the discharge; $n$ is the Manning's roughness coefficient, dimensionless; $A\left[\mathrm{~m}^{2}\right]$ is the cross-sectional area of the stream; $R[\mathrm{~m}]$ is the hydraulic radius; $S\left[\mathrm{~m} . \mathrm{m}^{-1}\right]$ is the hydraulic gradient slope, in case of constant water level it is equal to the streambed slope.

The discharge cross section area and the hydraulic radius for rectangular shape of streambed is:

$$
\begin{aligned}
& A=W \cdot d, \\
& R=\frac{W \cdot d}{W+2 d},
\end{aligned}
$$

where $A\left[\mathrm{~m}^{2}\right]$ is the cross-sectional area of the stream; $W[\mathrm{~m}]$ is the stream width; $d[\mathrm{~m}]$ is the stream depth; $R[\mathrm{~m}]$ is the hydraulic radius.

\section{SFR module}

The SFR module (Streamflow-Routing Package) [8] is a modification of the RIV module [4] and is designed as a part of the MODFLOW model. The package replaces an older STR module that was written for earlier versions of the MODFLOW model. The SFR module is designed to simulate GW-SW interactions and to route flow and a single solute through a network of surface water channels. The new version offers improved efficiency in the input of data and offers more options in computing the stream depth and width. The SFR module replaces the previous STR module. The most important difference is that the stream depth is computed at the midpoint of each reach instead of at the beginning of each reach, as was done in the original Stream Package. This approach allows for the addition and subtraction of water from runoff, precipitation, and evapotranspiration within each reach. The SFR Package has input of five options for simulation of the stream depth and four options for computing diversions from a stream. The options for computing stream depth are: a specified value; Manning's equation (using a wide rectangular channel or an eight-point cross section); a power equation; or a table of values that relate flow to depth and width. Each stream segment can have a different option. Because the wetted perimeter is computed for the eight-point cross section and width is computed for the power equation and table of values, the streambed conductance term no longer needs to be calculated externally whenever the area of streambed changes as a function of flow.

\section{Comparison of the numerical simulation outputs of the RIV, STR and SFR modules}

For the comparison of the outputs of these three kinds of simulations of GW-SW interactions using the RIV, STR and SFR packages each of the modules were used separately for the simulated GW-SW interaction in the idealized aquifer by the MODFLOW model. The parameters of the simulated idealized aquifer are (Table I). 
Table I

Parameters of the simulated aquifer

\begin{tabular}{|l|l|}
\hline Width & $1000 \mathrm{~m}$ \\
Length & $1000 \mathrm{~m}$ \\
Aquifer thickness & $60-90 \mathrm{~m}$ \\
Terrain elevation & $110-140 \mathrm{~m}$ \\
Coefficient of saturated hydraulic & $5.10^{-3} \mathrm{~m} \cdot \mathrm{s}^{-1}$ \\
conductivity & \\
\hline
\end{tabular}

There was no precipitation or evapotranspiration input in the simulation. The stream intersecting the central part of the modeled area has these parameters (Table II).

Table II

Parameters of the stream

\begin{tabular}{|l|l|}
\hline Width & $10 \mathrm{~m}$ \\
Length & $1000 \mathrm{~m}$ \\
Depth & $2 \mathrm{~m}$ \\
Bottom sediment layer thickness & $0.5 \mathrm{~m}$ \\
Surface water level & $1.36 \mathrm{~m}$ \\
Discharge & $50 \mathrm{~m}^{3} \cdot \mathrm{s}^{-1}$ \\
Bottom sediment - coefficient of & $5.10^{-5} \mathrm{~m} \cdot \mathrm{s}^{-1}$ \\
saturated hydraulic conductivity & \\
\hline
\end{tabular}

In case of the RIV module simulation it is needed to perform a surface water level simulation in an external application [14] Suitable applications include the U.S. Army Corps of Engineers, Hydrologic Engineering Center's River Analysis System (HECRAS) model and Danish Hydraulic Institute (DHI) Mike 11 model. Mike 11 is a 1-dimensional unsteady flow hydraulic model used for the simulation of flow in rivers [15]. The HEC-RAS [16] one-dimensional surface water model was used to perform the simulation. HEC-RAS is a one-dimensional application that computes the surface water levels between reaches of a stream by iteration of the energy equation. The surface water level was computed from input parameters. For the discharge of $50 \mathrm{~m}^{3} \cdot \mathrm{s}^{-1}$, the water level was computed as $1.36 \mathrm{~m}$. Therefore, the surface water level was set to $129.36 \mathrm{~m}$ a.s.l. for the south, and to $139.36 \mathrm{~m}$ a.s.l. for the north boundary. The output water stage was inputted to the MODFLOW model for the river boundary condition defined by the RIV module. The modules STR and SFR include the surface water regime simulation; therefore, it was not needed to use the external simulation for this purpose. MODFLOW model was also defined by other boundary conditions. Boundary condition on the north and south edges of the model grid is specified by GW head. The GW head was set to $128.5 \mathrm{~m}$ a.s.1. for the south boundary and $138.5 \mathrm{~m}$ a.s.l. for the north boundary. The groundwater table elevation was therefore set to a lower stage than the surface water level and to be higher than the streambed elevation (128 $\mathrm{m}$ a.s.l. and $138 \mathrm{~m}$ a.s.l. respectively). In the simulations, the water from the stream will infiltrate to the aquifer [17]. Fig. 4 shows the groundwater isolines from the RIV module simulation. 


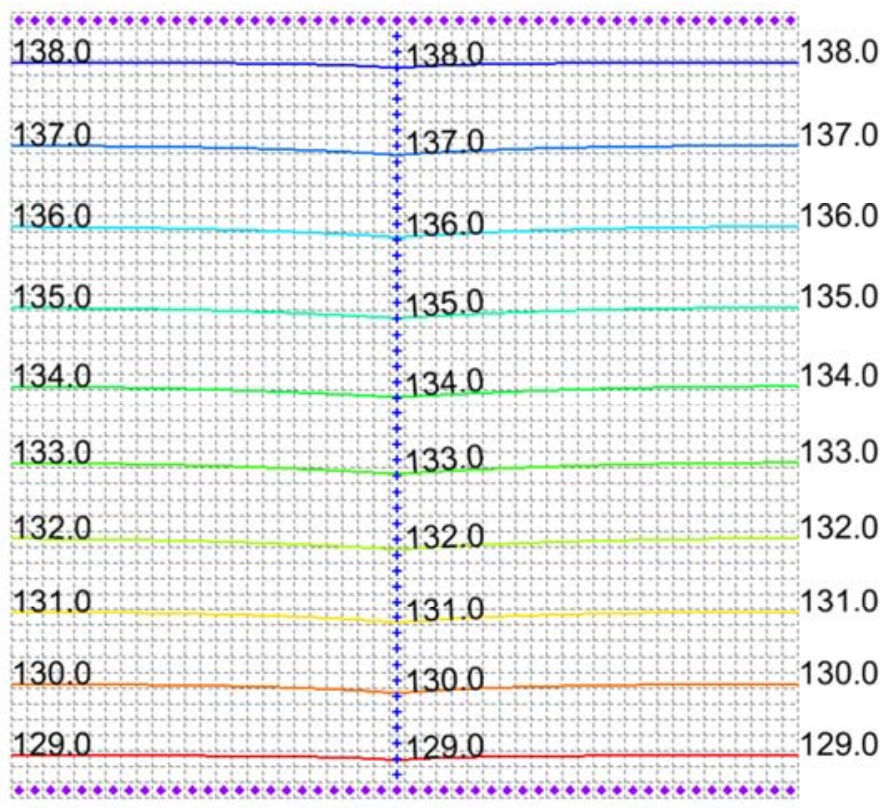

Fig. 4. Groundwater table elevations for the RIV module simulation

The differences between the groundwater levels are minimal for all three modules. The difference between the RIV module and STR module simulations is at maximum of 0.11 meters, the difference between the RIV and SFR simulation is -0.01 to 0.05 meters and the difference between the STR and SFR simulations is at maximum of -0.05 meters (Fig. 5 - Fig. 7).

The numerical representation of a stream - aquifer interaction is defined as a model balance of inflows and outflows of the model [18]. This balance in the MODFLOW model is called the FLOW BUDGET [3]. The model domain inflow and outflow influenced by the specified GW head is represented by the CONSTANT HEAD parameter (Flow IN for the inflow to aquifer and Flow OUT for the outflow from the aquifer) (Table III - Table V). The interaction between the river and aquifer is defined as the RIVER LEAKAGE (Table III) or STREAM LEAKAGE (Table IV - Table V) parameter (Flow IN as the flow into the aquifer and Flow OUT as the flow into the river). The total model domain parameters inflow and outflow is combined as a Total Source/Sink parameter (Table III - Table V). Table III to Table V represents the FLOW BUDGET for the RIV, STR and SFR module simulations respectively.

Considering the Table III - Table $V$ the difference in streambed seepage is also minimal. The range of the RIVER LEAKAGE and STREAM LEAKAGE values for the entire stream (50 model cells) is between 0.008 to $0.016 \mathrm{~m}^{3} . \mathrm{s}^{-1}$ (Fig. 8). 


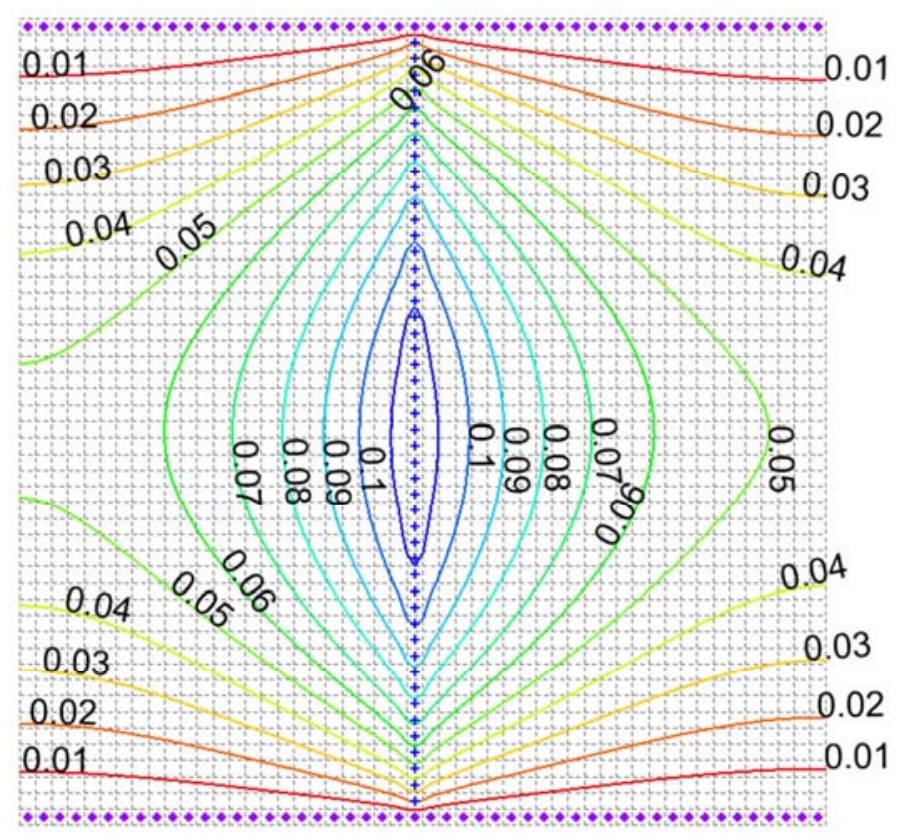

Fig. 5. The isolines of differences between groundwater table elevations, RIV and STR module

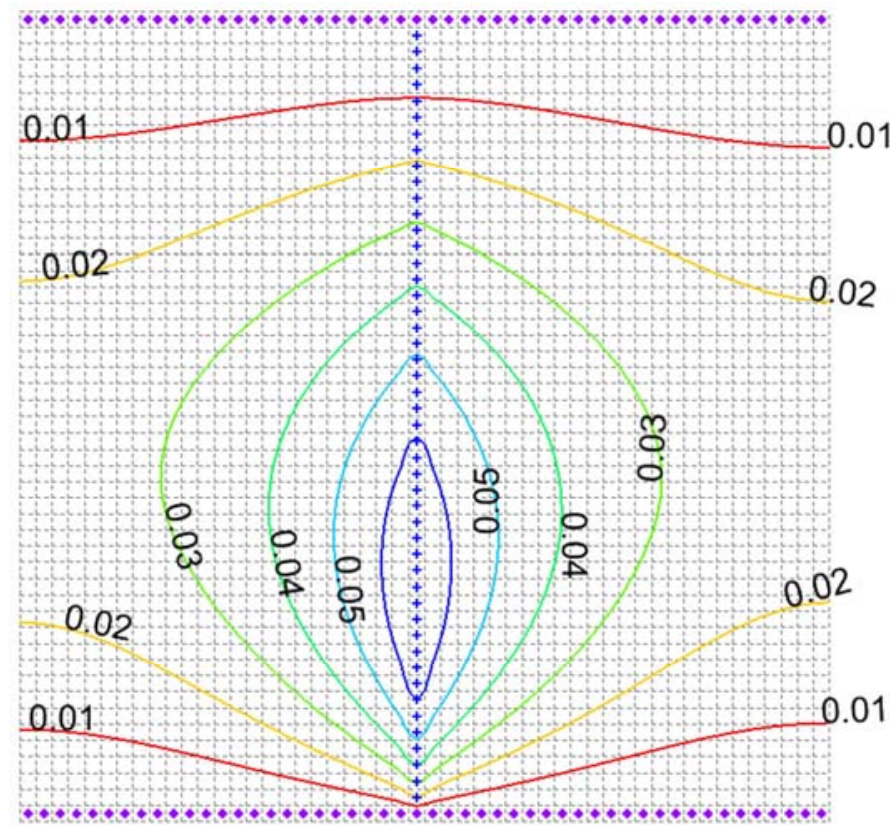

Fig. 6. The isolines of differences between groundwater table elevations: RIV and SFR module 


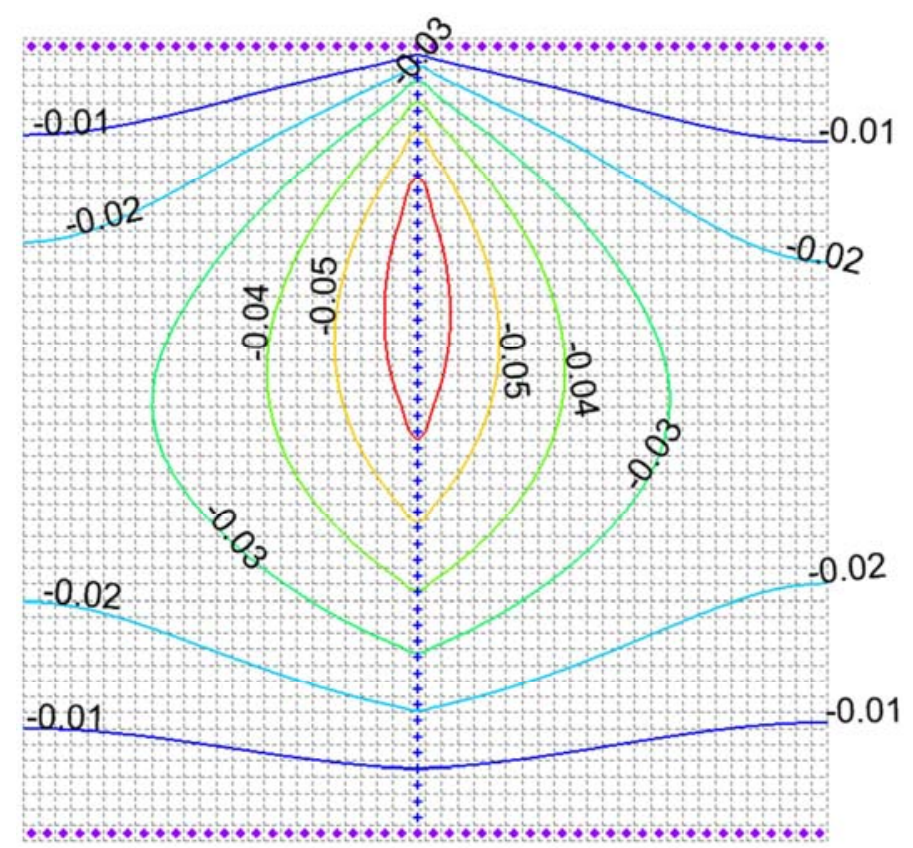

Fig. 7. The isolines of differences between groundwater table elevations: STR and SFR module

\section{Table III}

RIV module simulation FLOW BUDGET

\begin{tabular}{|l|l|l|}
\hline Sources/Sinks & Flow IN $\left(\mathrm{m}^{3} \cdot \mathrm{s}^{-1}\right)$ & Flow OUT $\left(\mathrm{m}^{3} \cdot \mathrm{s}^{-1}\right)$ \\
\hline CONSTANT HEAD & 0.11322 & -0.12872 \\
\hline RIVER LEAKAGE & $\mathbf{0 . 0 1 5 5 0}$ & 0 \\
\hline Total Source/Sink & 0.12872 & -0.12872 \\
\hline
\end{tabular}

Table IV

STR module simulation FLOW BUDGET

\begin{tabular}{|l|l|l|}
\hline Sources/Sinks & Flow IN $\left(\mathrm{m}^{3} \cdot \mathrm{s}^{-1}\right)$ & Flow OUT $\left(\mathrm{m}^{3} \cdot \mathrm{s}^{-1}\right)$ \\
\hline CONSTANT HEAD & 0.11684 & -0.12511 \\
\hline STREAM LEAKAGE & $\mathbf{0 . 0 0 8 2 6}$ & 0 \\
\hline Total Source/Sink & 0.12511 & -0.12511 \\
\hline
\end{tabular}

Table V

SFR module simulation FLOW BUDGET

\begin{tabular}{|l|l|l|}
\hline Sources/Sinks & Flow IN $\left(\mathrm{m}^{3} \cdot \mathrm{s}^{-1}\right)$ & Flow OUT $\left(\mathrm{m}^{3} \cdot \mathrm{s}^{-1}\right)$ \\
\hline CONSTANT HEAD & 0.11422 & -0.12617 \\
\hline STRAM LEAKAGE & $\mathbf{0 . 0 1 1 9 5}$ & 0 \\
\hline Total Source/Sink & 0.12617 & -0.12617 \\
\hline
\end{tabular}




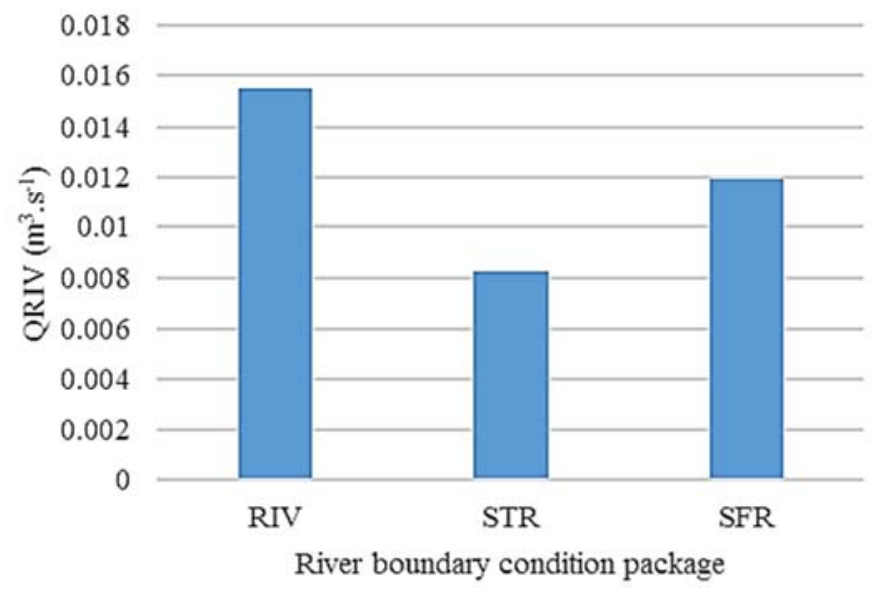

Fig. 8. The River/Stream leakage comparison for river boundary condition packages

\section{Conclusion}

Simulation of simplified idealized aquifer with a stream flowing through it proved that the computed differences in simulated groundwater table elevations for different approaches of the surface level computation are minimal. Therefore, the results of STR or SFR simulations are equally usable as a more laboring and time consuming process of simulation using the RIV module with the use of external 1D or 2D environment for simulation of the surface level (HEC-RAS, MIKE, SHE, etc.). However, this is applicable only for simplified problems. In the case of more complex problems with irregular shaped streambed it is needed to use the solution using external applications, or use the SFR module that includes more complex hydraulic parameters of stream into the simulation. The STR module is not applicable for more complex simulation because of the limitations of the input hydraulic parameters.

\section{Acknowledgements}

This work was supported by the VEGA Science Grant Agency under contract No. VEGA 2-0058-15 and by the Slovak Research and Development Agency under the contract No. APVV 14-0735.

\section{References}

[1] Barthel R., Banzhaf S. Groundwater and surface water interaction at the regional-scale, A review with focus on regional integrated models, Water Resources Management, Vol. 30, No. 1, 2016, pp 1-32.

[2] Harbaugh A. W. MODFLOW-2005, The U.S. geological survey modular groundwater model, the groundwater flow process, United States Geological Survey, 2005. 
[3] Maxwell R. M., Putti M., Meyerhoff S., Delfs J. O., Ferguson I. M., Ivanov V., Kim J., Kolditz O., Kollet S. J., Kumar M., Lopez S., Niu J., Paniconi C., Park Y. J., Phanikumar M. S., Shen C., Sudicky E. A., Sulis M. Surface subsurface model intercomparison, A first set of benchmark results to diagnose integrated hydrology and feedbacks, Water Resources Research, Vol. 50, 2014, pp. 1531-1549.

[4] McDonald M. G., Harbaugh A. W. A modular three, dimensional finite, difference groundwater flow model, United States Geological Survey, 1988.

[5] Harbaugh A. W., Banta E. R., Hill M. C., McDonald M. G. MODFLOW-2000, The U.S. geological survey modular groundwater model, User guide to modularization concepts and the groundwater flow process, United States Geological Survey, 2000.

[6] Ou G., Chen X., Kilic A., Bartelt-Hunt S., Li Y., Samal A. Development of a cross-section based streamflow routing package for MODFLOW, Environmental Modeling \& Software, Vol. 50, 2013, pp. 132-143.

[7] Osman Y. Z., Bruen M. P. Modeling stream-aquifer seepage in an alluvial aquifer: an improved loosing-stream package for MODFLOW, Journal of Hydrology, Vol. 264, 2002, pp. 69-86.

[8] Prudic D. E., Konikow L. F., Banta E. R. A new stream-flow-routing (SFR1) package to simulate stream-aquifer interaction package to simulate stream-aquifer interaction with MODFLOW-200, United States Geological Survey, 2004.

[9] Niswonger R. G., Prudic D. E. Documentation of the stream-flow-routing (SFR2) package to include unsaturated flow beneath streams, A modification to SFR1, United States Geological Survey, 2010.

[10] Morel-Seytoux H. J., Miller C. D., Miracapillo C., Mehl S. River seepage conductance in large-scale regional studies, Groundwater, 2016, doi:10.1111/gwat.12491.

[11] Červeňanská M., Baroková D., Šoltész A. Modeling the groundwater level changes in an area of water resources operations, Pollack Periodica, Vol. 11, No. 3, 2016, pp. 83-92.

[12] Tang Q., Kurtz W., Brunner P., Vereecken H., Hendricks Franssen H. J. Characterization of river-aquifer exchange fluxes: The role of spatial patterns of riverbed hydraulic conductivities, Journal of Hydrology, Vol. 531, Part 1, 2015, pp. 111-123.

[13] Ozbilgin M. M., Dickerman D. C. A modification of finite difference model for simulation of two-dimensional groundwater flow to include surface, groundwater relationships, United States Geological Survey, Water Resources Investigation Report, Vol. 83, 1984.

[14] Andrássy T., Baroková D. Numerical modeling of groundwater flow close to drinking water resources during flood events, Pollack Periodica, Vol. 11, No. 1, 2016, pp. 43-54.

[15] Ivanescu V., Mocanu P., Sandu M. A. Application of a hydrodynamic Mike 11 model for Argesel river, 14th SGEM GeoConference on Water Resources. Forest, Marine and Ocean Ecosystems, Albena, Romania, 17-26 June 2014, pp. 65-72.

[16] HEC-RAS river analysis system, User's manual, US Army Corps of Engineers, 2010.

[17] Velísková Y., Koczka Bara M., Dulovicová R., Schügerl R. Influence of surface water level fluctuation and riverbed sediment deposits on groundwater regime, Journal of Hydrology and Hydromechanics, Vol. 62, No. 3, 2014, pp. 177-185.

[18] Dušek P., Velísková Y. Input options of river boundary condition in MODFLOW model (in Slovak) Acta Hydrologica Slovaca, Vol. 17, No. 1, 2016, pp. 99-106. 